DOI

\title{
ОСОБЛИВОСТІ ВИКЛАДАННЯ МЕДИЧНОЇ РЕАБІЛІТАЦІЇ В СУЧАСНИХ УМОВАХ
}

\author{
І. Р. Мисула, Т. Г. Бакалюк, А. О. Голяченко, Л. В. Левицька, О. С. Квасніцька \\ ДВНЗ “Тернопільський державний медичний університет \\ імені I. Я. Горбачевського МОЗ України”
}
PECULIARITIES OF TEACHING OF MEDICAL REHABILITATION IN MODERN CONDITIONS

\author{
I. R. Mysula, T. H. Bakaliuk, A. O. Holiachenko, L. V. Levytska, O. S. Kvasnitska \\ SHEI "Ternopil State Medical University by I. Ya. Horbachevsky of MPH of Ukraine”
}

\begin{abstract}
У статті обцрунтована необхідність подальшого зміцнення матеріально-технічної та навчально-методичної бази кафедр медичної реабілітації у ВНЗ України. Актуальним у сучасних умовах є впровадження нових підходів до викладання медичної реабілітації, що обумовлено великою кількістю постраждалих після подій на Майдані і в зоні АТО, а також хворих, які потребують реабілітації після перенесених захворювань.
\end{abstract}

The article adduces the necessity of further strengthening of material and technical basis and educational and methodical basis of departments of medical rehabilitation in higher educational institutions of Ukraine. An urgent issue in modern conditions is the implementing of new approaches to the teaching of Medical Rehabilitation caused by the great quantity of damaged after the events on Maidan and in anti-terrorist operation area and also patients who need the rehabilitation after the previous diseases.

Вступ. Згідно з визначенням ВООЗ, реабілітація - це використання всіх доступних засобів, спрямованих на зменшення наслідків порушення функцій або інвалідизації індивідуума, з метою досягнення оптимальної соціальної інтеграції його в суспільство [4, 6].

Вдосконалення та розвиток методів реабілітації привели до розширення понять інвалідності та реабілітації. Розширення понять означає охоплення реабілітацією не лише осіб із моторними чи сенсорними порушеннями, але і осіб із розумовою відсталістю, хворих із психічними розладами, хронічними серцево-судинними та легеневими захворюваннями, хронічними шлунково-кишковими розладами, захворюваннями шкіри, раком, хронічним больовим синдромом, при захворюваннях нервової системи, особливо хворих, що перенесли інсульт, а також осіб із симптомами хронічного алкоголізму та наркоманії.

Одним із найбільш значущих питань, яке зараз озвучується у мас-медіа, виноситься на порядок денний засідань урядових комітетів та громадських організацій, $є$ вирішення проблем реабілітації учасників АТО. Багатогранність завдань медичної реабілітації постраждалих в АТО потребує ефективного функціонування системи медичної

( I. Р. Мисула, Т. Г. Бакалюк, А. О. Голяченко та ін. реабілітації як самостійного напрямку клінічної та соціальної медицини.

У МОЗ України створено окремий відділ медичної реабілітації та паліативної медицини, який куруватиме роботу цього напрямку. Розробкою наукових програм, протоколів реабілітації, методичним керівництвом реабілітаційних закладів займаються 9 науково-дослідних установ. У ВНЗ працюють 11 профільних кафедр і 3 кафедри у закладах післядипломної освіти. Клінічну базу складають 11 лікарень відновного лікування - всього 1888 ліжок, нині до них долучилися обласні госпіталі інвалідів війни - ще 7248 ліжок, 7 фізіотерапевтичних лікарень, понад 12000 ліжок ЗАТ “Укрпрофоздоровниці” та відомчих санаторно-курортних закладів.

Однак завдання, які має вирішувати реабілітаційна медицина, не закінчаться з останнім пострілом на війні чи з останнім виписаним із госпіталю солдатом. Це проблема найближчих десятиліть. I від того, хто ï вирішуватиме, залежить багато.

Розширення поняття реабілітації збільшило потребу в службах реабілітації.

Питання про те, як найкраще організувати служби реабілітації, дискутується протягом тривалого часу. Деякі країни стали здійснювати програми, що передбачають створення спеціалізованих відділів реабілітації (спеціалізований підхід). Інші країни зробили наголос на покращанні підготовки 
студентів-медиків за рахунок інтегрованого навчання методів реабілітації в поєднанні із профілактичними та лікувальними аспектами інвалідності. Такий підхід має за мету спонукати всіх лікарів до здійснення реабілітації як невід’ємної частини їх повсякденної роботи (неспеціалізований підхід). 3 метою покращання підготовки студентів та проведення наукових досліджень з цієї проблеми в університетах ряду країн створені кафедри медичної реабілітації.

Слід зазначити, що як спеціалізований, так і неспеціалізований підходи довели свою цінність. Тому при реорганізації медичної допомоги та підготовки кадрів у вищих навчальних закладах, яка назріла в Україні, слід раціонально використовувати обидва підходи.

Окремий досвід з цього питання набутий і в Тернопільському державному медичному університеті імені I. Я. Горбачевського, у якому ще з 1999 р. почав функціонувати курс медичної реабілітації, який на сьогодні $\epsilon$ кафедрою медичної реабілітації. Лікувальними базами кафедри є фізіотерапевтичні відділення лікарень Тернополя та санаторій “Медобори”. На кафедрі проходять підготовку з медичної реабілітації студенти VI курсу та лікаріінтерни всіх спеціальностей.

Підготовка кадрів у багатьох розвинутих країнах останні десятиліття характеризувалась високою спеціалізацією кадрів, які займаються реабілітацією, що привело до створення нових професійних груп та підгруп. Можна виділити основні наслідки цього процесу. По-перше, був прийнятий невиправдано високий рівень підготовки для осіб, що спеціалізуються в галузі реабілітації; окрім цього, професійні групи наполягали на ідеальній якості освіти та розширеному курсі навчання із включенням питань, які не стосуються безпосередньо реабілітації. По-друге, високий рівень спеціалізації зробив реабілітацію надто складною: до лікування одного хворого іноді залучалося декілька спеціалістів. Це призводило до невиправдано високих витрат, плутанини та конфліктів, а також юридичних суперечок між співробітниками. Тому комітет експертів ВООЗ із запобігання інвалідності та реабілітації прийняв рекомендації, щоб кожна країна проводила дослідження, спрямовані на пошуки шляхів спрощення існуючих кадрових структур та організації підготовки персоналу. При такому підході потреба в спеціалістах не скорочується і деякі спеціальності будуть збережені, проте необхідно перебудувати навчальні програми, щоб підвищити ефективність та якість підготовки персоналу, який займатиметься реабілітацією. При цьому слід включити вивчення окремих, менш складних, методів, які використовуються на даний час спеціалістами, в курс підготовки, насамперед, сімейних лікарів.

Важливим завданням, яке стоїть перед викладачами вищих навчальних закладів на сучасному етапі, $€$ впровадження нових методів навчання, піднесення їх на новий якісний рівень і втілення їх у життя, формування студента як особистості, громадянина, прищепити йому навики до постійного самостійного вдосконалення власної майстерності та обізнаності в умовах сучасного швидкозмінюваного світового наукового середовища [3].

Основна частина. В Тернопільському державному медичному університеті студенти VI курсу медичного факультету на кафедрі медичної реабілітації вивчають предмет “Медична реабілітація”, який інтегрує питання реабілітації пацієнтів практично при всіх існуючих патологіях. Медична реабілітація - це комплексна дисципліна, яка передбачає викладання студентам всього спектра знань, які пов’язані з реабілітацією серцево-судинних, ревматологічних, неврологічних, пульмонологічних та багатьох інших захворювань. Маючи необхідний об'єм знань з різних нозологій, використовуючи здобуті на попередніх курсах знання з фізіотерапії та фізичної реабілітації, студент здатний адекватно засвоювати предмет.

Основним завданнямнавчаннястудентів змедичної реабілітації $є$ формування навичок практичної діяльності, підготовки висококваліфікованого фахівця, який буде володіти необхідним об'ємом теоретичних знань, вміти застосовувати отримані знання на практиці. Виходячи 3 цього, основна мета проведення занять 3 медичної реабілітації досягти оптимізації якості навчання студентів шляхом збільшення об’єму наочного матеріалу, вивчення нових методів реабілітації та активна участь студента в науково-дослідній роботі.

Новим якісним етапом у викладанні медичної реабілітації $є$ вивчення питань наукового забезпечення етапів реабілітації: ознайомлення з новими методами і технологіями використання основних лікувальних чинників; обгрунтування критеріїв ефективності реабілітаційного етапу на підставі уніфікованих технологій; складання індивідуальних програм медичної реабілітації при різних патологіях; застосування стандартів відновного лікування. 
Мотивований інтерес до вивчення предмета пробуджується після ознайомлення 3 лікувальною базою фізіотерапевтичних, реабілітаційних відділень та санаторіїв, що дозволяє на практиці продемонструвати позитивні сторони засобів та методів медичної реабілітації, а також закріпити мотивацію, яка виникла і спонукає до активного освоєння практичних вмінь та навичок. На практичному занятті, яке, як правило, проходить в санаторному закладі або у відділенні реабілітації, демонструються різноманітні методи та засоби медичної реабілітації, починаючи від класичних i завершуючи сучасними, також у студентів є можливість опанувати методикою проведення та оцінити можливості методів лікування. Це не тільки закріплює інтерес, який виник до інформації, але і мобілізує студента на активне оволодіння технікою проведення методик та дає можливість зрозуміти адекватність застосування методів на різних етапах реабілітації.

Участь у впровадженні нових методик є активним методом оволодіння інформації, створюється сприятливий для навчання клімат, оскільки вся група бере активну участь у дослідженні методу,

\section{Список літератури}

1. Золотарева Т. А. Медицинская реабилитация / Т. А. Золотарева, К. Д. Бабов. - К. : КИМ, 2012. - 496 с.

2. Медична та соціальна реабілітація : навч. посіб. / за заг. ред. І. Р. Мисули, Л. О. Вакуленко. - Тернопіль : ТДМУ, 2005. - 402 с.

3. Медицинская реабилитация в Украине: современное положение и перспективы развития / В. Н. Сокрут, В. Н. Казаков, В. Я. Уманский [и др.] // Новости медицины и фармации в мире. - 2003. - № 10 (138). С.19-20. також це дає студенту зрозуміти, що почуває пацієнт під час застосування деяких видів реабілітаційного лікування.

Висновки. Тільки при використанні різних методологічних підходів, спрямованих на активне мотивоване оволодіння студентами конкретної теми, забезпечується максимальне підвищення рівня професійності. Нові умови породжують і нові вимоги до процесу навчання та, звичайно, до викладача.

Оскільки студент виступає як активний елемент системи навчання, тобто бере активну участь у науково-дослідній роботі, вивченні нових методів реабілітації, - це сприяє поглибленню теоретичних та практичних знань з медичної реабілітації. Для викладача сьогодні важливо постійно вдосконалювати власні знання про методи навчання, впроваджувати у власну викладацьку практику новітні освітні концепції, йти в ногу з часом та виховувати плеяду конкурентоспроможних майбутніх фахівців на ринку надання медичних послуг. Разом з тим, впровадження в клінічну практику нової діагностичної апаратури, нових методик у проведенні відновного лікування висуває нові вимоги до якісного рівня підготовки лікарів.

4. Международная классификация функционирования, ограничений жизнедеятельности и здоровья. - Женева : Всемирная организация здравоохранения, 2001. 342 c.

5. Сучасні стандарти та критерії в галузі реабілітаційної медицини / ред. В. П. Лисенюк. - К. : НМУ, 2001. -71 c.

6. World Health Organization (WHO). International classification of impairments, disabilities, and handicaps (ICIDH). - Geneva : WHO, 1980. - 175 p. 